\title{
Pakistan - nierównowaga kontroli między establishmentem militarno-wywiadowczym a cywilnym i fasadowa demokratyzacja
}

\author{
Pakistan: Civil-military Imbalance of \\ Control and Façade Democratisation
}

Słowa kluczowe: Pakistan, reżim hybrydowy, demokratyzacja, Azja Południowa, relacje patron-klient

Keywords: Pakistan, hybrid regime, democratisation, South Asia, patron-client relationship

Abstrakt: Po dwóch demokratycznych przejęciach władzy w 2013 i 2018 r. Pakistan pozostaje reżimem hybrydowym. Establishment militarno-wywiadowczy wciąż kontroluje kluczowepolitykiwpaństwie. Przyczynamitejnierównowagikontrolisa (i)braksilnejklasy politycznej, (ii) nieoficjalny sojusz establishmentu militarno-wywiadowczego z organizacjami o charakterze religijnym, (iii) zagrożenia zewnętrzne, które z jednej strony wynikaja $z$ niezależnych od Islamabadu uwarunkowań geopolitycznych, a $z$ drugiej sq eskalowane przez establishmentmilitarno-wywiadowczy, ponieważlegitymizuja jego dominująca pozycję.

Abstract: After two democratic transitions of power in 2013 and 2018, Pakistan remains a hybrid regime. The military-security establishment continues to control key policies in the country. The causes of this imbalance of control are (i) the lack of capable political elites, (ii) an unofficial alliancebetween military-security establishmentand religiousorganisations,

(iii) external threats. On the one hand, these threats result from geopolitics that does not depend on Islamabad; on the other hand, they are escalated by the military-security establishment to legitimise its dominant position.

* ORCID ID: https://orcid.org/0000-0002-1677-986X, doktor, Collegium Civitas. Email: agnieszka.nitza@civitas.edu.pl. 


\section{Wprowadzenie}

Pomimo marginalizującej charakterystyki państwa ideologicznego, zagrożonego terroryzmem, czy państwa klienckiego w relacjach z sojusznikami w Waszyngtonie i Pekinie, Pakistan ze swoim arsenałem nuklearnym oraz strategicznym położeniem geograficznym pozostaje kluczowym aktorem stosunków międzynarodowych. U schyłku drugiej dekady XXI w. jego wewnętrzną dynamikę polityczną kształtują dwa pozornie sprzeczne ze sobą procesy. Pierwszy z nich, zamanifestowany puczem wojskowym z 1958 r., dotyczy zawłaszczania państwa, w tym jego najważniejszych polityk, przez establishment militarno-wywiadowczy. Drugi proces, zasygnalizowany demokratycznym przejęciem władzy w 2013 r., można nazwać fasadową demokratyzacją. Zarówno historia Pakistanu, jak i wydarzenia bieżące dowodzą, że pierwszy z procesów pozostaje nadrzędny wobec drugiego. Proces fasadowej demokratyzacji zachodzi pod warunkiem przyzwolenia ze strony establishmentu militarno-wywiadowczego, a wybierani przez elektorat reprezentanci nie decydują samodzielnie w obszarach, które są kluczowe dla (prze)trwania państwa, jak bezpieczeństwo (wewnętrzne i zewnętrzne) czy polityka zagraniczna ${ }^{1}$. Dlatego pomimo dwóch demokratycznych przejęć władzy w 2013 i 2018 r., Pakistan pozostaje reżimem hybrydowym o cechach państwa demokratycznegoi autorytarnego. Nazywając państwo demokracją popełnilibyśmy błąd elektoralizmu (fallacy of electoralism, electoral fallacy), który polega na uznaniu wyborów jedynym warunkiem demokracji, i w konsekwencji automatycznym utożsamianiu państw, gdzie odbywają się wybory z państwami demokratycznymi.

Dominujący na pakistańskiej scenie politycznej establishment militarno-wywiadowczy tworzą: wojsko, służby specjalne (Inter-Services Intelligence, ISI) oraz trudna do zdefiniowania grupa związanych z tymi instytucjami obywateli włączając rodziny obecnych i emerytowanych oficerów. Wewnętrzną nierównowagę kontroli² między tym establishmentem a politykami cywilnymi, ukształtowały: (i) brak silnej klasy politycznej widoczny już w pierwszej dekadzie po powstaniu państwa w 1947 r., (ii) nieoficjalny sojusz establishmentu militarno-wywiadowczego z partiami religijnymi, silnie zacieśniany przez gen. Zięul-Haqa,

${ }^{1}$ A. Shah, Pakistan: Voting Under Military Tutelage, «Journal of Democracy» 2019, nr 1, s. $128-142$.

${ }^{2}$ A. Nitza-Makowska używa sformułowania nierównowaga kontroli między establishmentem cywilnym a militarno-wywiadowczym tłumacząc fiaska demokracji w Pakistanie;

A. Nitza-Makowska, Różnice demokracji: Indie i Pakistan, Warszawa 2019. 
dyktatora, który rządził krajem w latach 1977-1988, oraz (iii) zagrożenia zewnętrzne, które z jednej strony wynikają z niezależnych od Islamabadu uwarunkowań geopolitycznych, a z drugiej są eskalowane przez establishment militarno-wywiadowczy, ponieważ legitymizująjego dominującą pozycję $\mathrm{w}$ państwie.

Niniejszy artykuł analizuje nierównowagę kontroli między establishmentem militarno-wywiadowczym a cywilnym w Pakistanie. Co interesujące z punktu widzenia badaczy demokratyzacji, ta wewnętrzna nierównowaga utrzymuje się niezależnie od charakteru reżimu politycznego - dlatego podkreśla się fasadowy charakter procesu demokratyzacji; oraz partii u władzy. Przetrwanie obecnego rządu Imrana Khana, tak jak i rządów jego poprzedników, w znacznym stopniu zależy od przychylności establishmentu militarno-wywiadowczego. Co więcej, przedstawione w artykule spojrzenie na wewnętrzną dynamikę polityczną Pakistanu, pomaga zrozumieć działania i miejsce państwa na arenie międzynarodowej.

\section{Reżim hybrydowy}

Dwa procesy, które dominują pakistańską scenę polityczną czyli zawłaszczanie państwa przezestablishment militarno-wywiadowczy oraz fasadowa demokratyzacja zachodzą w warunkach systemu politycznego Islamskiej Republiki Pakistanu. Choć konstytucja z 1973 r. zakłada, że Pakistan będzie demokracją ${ }^{3}$, organizacje, które prowadzą badania porównawcze nad systemami politycznymi w skali globalnej (Freedom House (FH), Polity IV) bardziej surowo oceniają pakistański reżim.

Od 1972 r., kiedy FH po raz pierwszy zbadał poziom wolności na świecie, ocena Pakistanu wahała się. Islamskiej Republice przyznawano status państwa pozbawionego wolności (1979-1984) lub częściowo wolnego (1972-1978; od 1985). W latach 1988-1998 oraz 2013-2016 FH klasyfikował Pakistan jako demokrację elektoralną (electoral democracy) ${ }^{4}$. Choć

${ }^{3}$ Constitution of the Islamic Republic of Pakistan of 1973 (tekst ogłoszony 28 lutego 2012 r.), Preambuła, s. 1-2, http://www.na.gov.pk/uploads/documents/1333523681_951. pdf (3.02.2020).

${ }^{4} \mathrm{FH}$ ocenia czy państwo jest demokracją elektoralną na podstawie części wskaźników służących do mierzenia stanu wolności. Badanie uwzględnia wymiar polityczny, w tym przede wszystkim trzy kwestie: 1) czy szef rządu lub inne władze państwowe zostały wyłonione w drodze sprawiedliwych wyborów, 2) czy członkowieciałustawodawczych na poziomie państwa zostali wyłonieni w drodze sprawiedliwych wyborów, 3) czy istnieje wolna i otwarta wymiana poglądów politycznych w sferze prywatnej. Od 1989 r., kiedy 
w Pakistanie przeprowadza się wybory, w 2017 r. państwo straciło status demokracji elektoralnej. Za spadek pozycji Pakistanu odpowiedzialne były kontrola armii nad procesem odwołania przez Sąd Najwyższy ówczesnego premiera Nawaza Sharifa w czerwcu 2017 r., oraz umocnienie się pozycji establishmentu militarno-wywiadowczego po rezygnacji premiera i wymuszonych dymisjach innych polityków z Pakistańskiej Ligi Muzułmańskiej (Nawaz) (Pakistan Muslim League (Nawaz), PML(N)) 5 .

Tak samo, na dużą dynamikę trajektorii ustrojowej Pakistanu wskazuje miernik opracowany przez badaczy z projektu Polity. W latach 1958-1961 oraz 1977-1984 Polity ocenia Pakistan najniżej w historii (-7). Najwyżej (8), oceniono w latach 1956-1957, 1973-1976 oraz 1988-1996 (wykres 1).

Wykres 1. Trajektoria ustrojowa Pakistanu

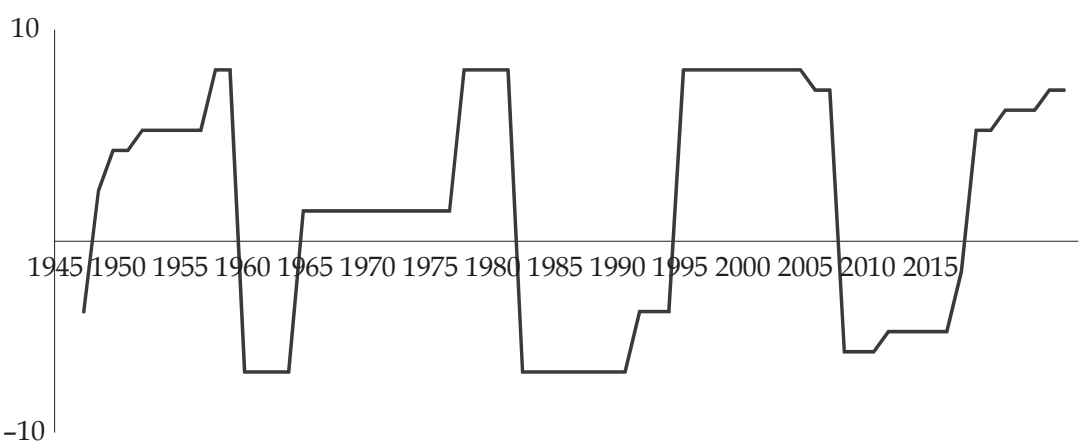

-10 do -6 - autokracja; -5 do 0 - zamknięta anokracja; 1 do 5 - otwarta anokracja; 6 do 9 - demokracja; 10 - pełna demokracja.

Źródło: Center for Systemic Peace, Authority Trends: 1946-2013: Pakistan, 2014, https://www. systemicpeace.org/polity/pak2.htm (6.02.2020).

Zaznaczone przez FH i Polity IV załamania procesu demokratyzacji zostały spowodowane przez zamachy stanu w 1958, 1977 oraz 1999 r. Ponadto, według badań Polity IV, Pakistan kilkukrotnie w relatywnie krótkim okresie czasu przechodził wręcz błyskawiczną transformację ustrojową. Choćby w 1988 r., kiedy w katastrofie lotniczej zginął Zia ul-Haq

FH wprowadził kategorię demokracji elektoralnej, liczba tych demokracji wzrosła z 69 do 116 w 2017 r. Kraje te zamieszkuje ok 60\% światowej populacji; Freedom House, Freedom in the World 2018, https://freedomhouse.org/report/freedom-world-2018-tablecountry-scores (3.02.2020).

5 FH, Freedom in the World 2018 - Pakistan, Freedom House, Freedom in the World 2018 - Pakistan, https://freedomhouse.org/report/freedom-world/2018/pakistan (3.02.2020). 
(wówczas prezydent i Naczelny Dowódca Sił Zbrojnych (Chief of Army Staff, COAS)), Pakistan został sklasyfikowany jako demokracja (8 pkt.), a rok wcześniej jako zamknięta anokracja ${ }^{6}(-4$ pkt.) (Wykres 1$)$. Faktycznie, u schyłku zainstalowanego po zamachach stanu reżimu wojskowego (jak i kolejnej dyktatury wojskowej Perveza Musharrafa (1999-2008)) w 1988 r. przeprowadzono wybory do Zgromadzenia Narodowego, ale proces demokratyzacji nie przebiegał tak szybko i sprawnie jak sugerują badania Polity. Same wybory jedynie symbolicznie go inicjowały.

Pomimo demokratycznego przejęcia władzy w 2013 r., badacze klasyfikują Pakistan jako reżim hybrydowy. W 2017 r. brytyjska politolog Katharine Adeney, przeanalizowała naturę tego systemu politycznego biorąc pod uwagę trzy wymiary: (i) proces wyborczy (electoral regime) w tym: wybierani reprezentanci, czynne i bierne prawo wyborcze, organizacja wolnych i równych wyborów; (ii) wolności obywatelskie (civil liberties) w tym: wolność prasy, wolność stowarzyszania się, rządy prawa; oraz (iii) zarezerwowane obszary władzy (reserved domains) w tym bezpieczeństwo zewnętrzne i wewnętrzne, organizacja armii, polityka publiczna, selekcja elit ${ }^{7}$. Ostatni z trzech głównych wymiarów dotyczy zawłaszczenia obszarów władzy przez establishment militarno-wywiadowczy. Spojrzenie na pakistański system polityczny przez pryzmat zaproponowanych przez Adeney wymiarów pozwala rozróżnić cechy pakistańskiego systemu politycznego, które są typowe dla demokracji i państwa autorytarnego. Badaczka najwyżej ocenia pakistański reżim w pierwszym z wymiarów, proces wyborczy - ponieważ w Pakistanie odbywają się wybory, które były coraz lepiej, aż do czasu wyborów powszechnych z 2018 r., oceniane przez międzynarodowych obserwatorów, a najniżej w drugim, wolności obywatelskie. Wciąż jednak, mając na uwadze trajektorię pakistańskiego reżimu, która wskazuje na pucze wojskowe jako na przyczynę nagłych odwrotów od demokratyzacji (Wykres 1) oraz badania FH, to wewnętrzna nierównowaga kontroli na pakistańskiej scenie politycznej, a więc trzeci z wymiarów, które wyróżniła Adeney, stanowi najtrwalszą barierę dla demokratyzacji w Pakistanie.

${ }^{6}$ Anokracja - system polityczny posiadający cechy demokracji i państwa autorytarnego. Terminu używa się w odniesieniu do systemów politycznych państw, w których wybrani w drodze wyborów decydenci są kontrolowani są przez innych aktorów sceny politycznej. Współcześnie w badaniach nad procesami demokratyzacji, poza badaniami Polity IV, termin jest rzadko stosowany.

${ }^{7} \mathrm{~K}$. Adeney, How to Understand Pakistan's Hybrid Regime: the Importance of a Multidimensional Continuum, «Democratization» 2017, nr 24 (1), s. 119-137. 


\section{Nierównowaga kontroli między establishmentem militarno-wywiadowczym a cywilnym}

\section{Brak silnej klasy politycznej}

Działając w warunkach niepodległego państwa, do $1971 \mathrm{r}$. tworzonego przez Pakistan Zachodni (obecnie Pakistan) i Pakistan Wschodni (obecnie Bangladesz), partia założycielska Pakistanu Liga Muzułmańska (Muslim League, ML lub Liga) ${ }^{8}$, była niezdolna do dzielenia się władzą z reprezentantką bengalskiej większości czyli Awami League (AL). Etniczna struktura nowo powstałego państwa, gdzie mieszkańcy wschodniego skrzydła stanowili - według spisu ludności z 1951 r. $-55 \%$ populacji ${ }^{9}$ skutecznie zniechęcała ML do demokracji. W szeregach Ligi demokrację rozumiano jako system działający wyłącznie na korzyść większości. Takie statystyczne podejście do tego ustroju politycznego było zakorzenione w doświadczeniach i obawach partii z czasów Imperium Brytyjskiego, gdzie muzułmanie byli jedną z mniejszości. W konsekwencji, ML sceptycznie podchodziła do samej koncepcji i tym samym organizacji wyborów powszechnych ${ }^{10}$, które z uwagi na strukturę etniczną ówczesnego Pakistanu musiały - jeśli nie zostałyby sfałszowane-przynieść zwycięstwo Bengalczyków z AL. Zwlekając z wprowadzeniem konstytucji - pierwsza weszła w życie w 1956 r. czyli dziewięć lat po uzyskaniu niepodległości - oraz organizacją bezpośrednich wyborów do Zgromadzenia Narodowego, założycielska partia Pakistanu nie przeszła transformacji z ruchu niepodległościowego w skuteczną partię polityczną. W konsekwencji porażki w budowaniu państwa, Liga traciła poparcie, w końcu w 1958 r. doszło do zamachu stanu, ogłoszono stan wojenny i zdelegalizowano partie polityczne. ML przestała istnieć.

Do fiaska działań ML, poza powyższymi zaniechaniami, przyczynił się nieszczęśliwy zbieg okoliczności. Charyzmatyczny lider partii, ojciec założyciel Pakistanu, którego wizerunek obecnie wykorzystują niemalże wszystkie partie polityczne - od odłamów Pakistańskiej Ligi Muzułmańskiej przez rządzący od lipca 2018 r. Pakistański Ruch na rzecz Sprawiedliwości (Pakistan Tehreek-e-Insaf,PTI) po islamistyczne ugrupo-

\footnotetext{
${ }^{8}$ Przed podziałem subkontynentu partia działała pod nazwą Ogólnoindyjska Liga Muzułmańska (All Pakistan Muslim League).

${ }^{9}$ Ch. Jaffrelot, India and Pakistan: Interpreting the Divergence of Two Political Trajectories, «Cambridge Review of International Affairs» 2002, nr 2, s. 257.

${ }^{10} \mathrm{Z}$ uwagi na takie nastawienie do demokracji, Maya Tudor nazywa ML partią antydemokratyczna;; M. Tudor, The Promise of Power. The Origins of Democracy in India and Autocracy in Pakistan, Cambridge University Press, Cambridge 2013. s. 61-65.
} 
wania, którym odmawia się statusu partii politycznej jaki Milli Muslim League (MML) - Muhammad Ali Jinnah zmarł zaledwie ponad rok po powstaniu Pakistanu.

Pierwsze bezpośrednie wybory powszechne przeprowadzono dopiero 23 lata po uzyskaniu niepodległości w 1970 r. Jednak ani one, ani kolejne nie doprowadziły do ukształtowania się właściwych dla państwa demokratycznego stosunków między establishmentem militarno-wywiadowczym a politykami cywilnymi. Zamachy stanu i instalowane $w$ ich następstwie wojskowe dyktatury skutecznie hamowały ewentualny proces transformacji ustrojowej. W konsekwencji wybory do Zgromadzenia Narodowego aż do 2008 r., przeprowadzano nieregularnie (tabela 1).

Tabela 1. Bezpośrednie wybory do Zgromadzenia Narodowego i reżimy wojskowe w Pakistanie do 2018 r.

\begin{tabular}{|c|c|c|}
\hline $\begin{array}{c}\text { Rok } \\
\text { wyborów }\end{array}$ & $\begin{array}{c}\text { Partia, która } \\
\text { zwyciężyła }\end{array}$ & $\begin{array}{c}\text { Reżim wojskowy/powód rozwiązania Zgromadzenia } \\
\text { Narodowego }\end{array}$ \\
\hline 1970 & AL & $\begin{array}{l}\text { Reżim Ayuba Khana (1958-1969) } \\
\text { Reżim Yahyi Khana (1969-1971) }\end{array}$ \\
\hline 1977 & PPP & \multirow{2}{*}{$\begin{array}{l}\text { Establishment cywilny nie zdołał zaradzić protestom opozycji, } \\
\text { władzę przejęło wojsko. Premier (Zulfikar Bhutto) zostaje odsu- } \\
\text { nięty od władzy przez COAS (Zię ul-Haqa), którego sam powołał. } \\
\text { Reżim Zii ul-Haqa (1977-1988) }\end{array}$} \\
\hline 1985 & $\begin{array}{l}\text { Wybory bez } \\
\text { udziału partii } \\
\text { politycznych }\end{array}$ & \\
\hline 1988 & PPP & $\begin{array}{l}\text { Pod naciskiem armii (a oficjalnie na mocy ósmej poprawki do } \\
\text { konstytucji - z powodu korupcji i nadużyć władzy) prezydent } \\
\text { (Ghulam Ishaq Khan) rozwiązał Zgromadzenie Narodowe } \\
\text { (z Benazir Bhutto jako premierem) i Zgromadzenia Prowincji } \\
\text { w Sindhu i NWFP. }\end{array}$ \\
\hline 1990 & PML(N) & $\begin{array}{l}\text { W obliczu konfliktu między premierem (Nawazem Sharifem) } \\
\text { a prezydentem (Ghulam Ishaq Khanem) armia skłoniła obu } \\
\text { polityków do rezygnacji. }\end{array}$ \\
\hline 1993 & PPP & $\begin{array}{l}\text { Pod naciskiem armii (a oficjalnie z powodu korupcji i nadużyć } \\
\text { władzy), prezydent odwołał premier (Benazir Bhutto) i jej rząd. }\end{array}$ \\
\hline 1997 & $\operatorname{PML}(\mathrm{N})$ & \multirow{2}{*}{$\begin{array}{l}12 \text { października } 1999 \text { r. COAS (Pervez Musharraf) przeprowa- } \\
\text { dza zamach stanu, po tym jak premier (Nawaz Sharif) próbuje } \\
\text { zastąpić go szefem ISI. } \\
\text { Reżim Perveza Musharrafa (1999-2008) }\end{array}$} \\
\hline 2002 & PML(Q) & \\
\hline 2008 & PPP & \multirow{3}{*}{-} \\
\hline 2013 & $\operatorname{PML}(\mathrm{N})$ & \\
\hline 2018 & PTI & \\
\hline
\end{tabular}

Źródło: opracowanie własne. 
Od zakończenia dyktatury Musharrafa establishment militarno-wywiadowczy formalnie nie sprawuje władzy, choć faktycznie wciąż kontroluje państwo i jego polityki. Zdarza się, że ignorując establishment cywilny, establishment militarno-wywiadowczy realizuje własne interesy w celu utrzymania korzystnej dla siebie wewnętrznej nierównowagi kontroli. W tym kontekście, wystarczy wspomnieć wydarzenia z jesieni 2017 r., kiedy wojsko podsycało antyrządowe manifestacje skutkujące blokadą Islamabadu i kilku innych miast w Pakistanie. Wsparcie to dokumentuje udostępniony przez BBC materiał filmowy, na którym oficer pakistańskiej armii wręcza protestującym pieniądze ${ }^{11}$. Oficjalnie, organizatorka protestów islamistyczna partia Tehreek-e-Labbaik Pakistan (TLP) rozpoczęła manifestację z powodów ideologicznych, kontestując propozycję zmiany słów przysięgi parlamentarnej, która - jak uznali protestujący - kwestionuje Khatam-e-Nabuwat, czyli dogmat głoszący, że Mahomet jest ostatnim prorokiem. Faktycznie, protesty miały skompromitować rząd PML(N) i samego Nawaza Sharifa przed wyborami do Senatu i Zgromadzenia Narodowego. Działania TLP można ocenić jako skuteczne. Choć jeszcze w marcu 2018 r. PML(N) zwyciężyła zdobywając 15 mandatów w Senacie wobec 12 dla Pakistańskiej Partii Ludowej (Pakistan Peoples Part, PPP) i siedmiu dla PTI, to już w lipcu tego samo roku wybory parlamentarne przyniosły porażkę partii Sharifa. PML(N) zdobyła 82 mandaty w Zgromadzeniu Narodowym w porównaniu do 149 dla zwycięskiej PTI.

\section{Establishment militarno-wywiadowczy i partie religijne}

Okoliczności wydarzeń z jesieni 2017 r. obnażają charakter relacji między establishmentem militarno-wywiadowczym a organizacjami islamistycznymi jak TLP. Ich bieżąca dynamika przywołuje okres rządów gen. Zii ul-Haqa, choć od śmierci dyktatora minęły ponad trzy dekady. Zia ul-HaqzislamizowałPakistani społeczeństwom.in.wprowadzająchudud - islamski kodeks karny ${ }^{12}$. Poza tym, dyktator wyrażał swoją przychylność wobec partii religijnych manipulując ordynacją wyborczą. W 1985 r. Zia

\footnotetext{
${ }^{11}$ M. Ilyas Khan, Why was Pakistan General Giving Money to Protesters?, 29.11.2017, BBC News, http://www.bbc.com/news/world-asia-42149535 (3.02.2020).

12 Prawa regulujące kwestię Zina (cudzołóstwa) oraz Qazf (fałszywego oskarżenia o cudzołóstwo) zostały zniesione dopiero przez Women's Protection Bill w 2006 r.; zgodnie z prawodawstwem wprowadzonym przezZię, mężczyźnie i kobiecie, którzy dopuścili się cudzołóstwa groziła kara ukamienowania - jeśli pozostawali w związkach małżeńskich, lub publicznej chłosty - jeśli byli stanu wolnego.
} 
przeprowadziłbezpośrednie, ale bezpartyjne wybory „mając nadzieje, że brak partii politycznych zwiększy szanse kandydatów popieranych przez wojsko oraz związanych z partiami religijnymi" 13 .

Kierunek wyznaczony przez Zię ul-Haqa jest kontynuowany ${ }^{14}$. Pakistański system polityczny otwiera się już nie tyle na islamskie partie polityczne, których funkcjonowanie koreluje z religijnym charakterem Islamskiej Republiki, co organizacje islamistyczne ${ }^{15}$. Organizatorka wspomnianych protestów, TLP wyrosła z kultu Mumtaza Qadri, mordercy Gubernatora Pendżabu Salmana Taseera. Polityk zginął w 2011 r. ponieważ publicznie stanął w obronie oskarżonej o bluźnierstwo Asi Bibi, pakistańskiej chrześcijanki, uniewinnionej siedem lat po tym morderstwie. Partia, która gloryfikuje skazanego przez sąd zabójcę jest nie tylko wspierana przez establishment militarno-wywiadowczy, ale także legalna. Jesienią 2017 r. TLP wzięła udział - choć jeszcze nieoficjalnie, bo jej kandydat wystartował jako niezależny - w wyborach uzupełniających na miejsce zwolnione po rezygnacji Nawaza Sharifa (NA-120), a później latem 2018 r. już oficjalnie pod własną nazwą w wyborach do Zgromadzenia Narodowego i Zgromadzenia Prowincji Sindh, zdobywając swoje pierwsze trzy mandaty w drugim ze Zgromadzeń.

Inną islamistyczną organizacją, która usiłowała zalegalizować swoją działalność rejestrując się jako partia polityczna jest MML, czyli kolejna manifestacja Lashkar-e-Taiba (LeT) antyindyjskiej organizacji terrorystycznej odpowiedzialnej m.in. za atak w Bombaju z 2008 r. (166 ofiar śmiertelnych). Choć na okoliczność wyborów powszechnych w 2018 r. Pakistańska Komisja Wyborcza odmówiła uznania MML jako partii politycznej, jej członkowie wystartowali w wyborach z list mało znanej Allah-o-Akbar Tehree (AAT). Żaden z kandydatów wystawionych przez partię nie zdobył mandatu. W warunkach fasadowej demokratyzacji - pomimo działań Pakistańskiej Komisji Wyborczej - poza wpływami natury nieformalnej, islamiści zupełnie legalnie, bo w drodze wyborów, zdobywają narzędzia do kształtowania polityk kraju.

${ }^{13}$ H. Haqqani, Pakistan. Between Mosque and Military, Lahore 2005, s. 155.

14 I.A. Rehman, How Zia Redefined Pakistan, «Dawn», 5 lipca 2018, https://www.dawn.com/ news/1342765 (3.02.2020).

15 Zob. P.Kłodkowski, Rządy Boga czy system demokracji-ideologiczny spórokształtRepubliki Islamskiej Pakistanu w XXi w XXI wieku, «Studia Politologiczne» 2019, vol. 53. 


\section{Zagrożenia zewnętrzne?}

Pakistan leży między potężnymi i wrogimi Indiami oraz wcale nie bardziej przyjaznym i upadającym Afganistanem. O ile pakistański establishment nie ma wpływu na położenie geograficzne państwa, o tyle może podejmować próby kształtowania polityk zagranicznych w celu normalizacji relacji z sąsiadami. W przypadku Pakistanu próby te, jeśli były podejmowane (przede wszystkim przez establishment cywilny), okazywały się nieskuteczne.

Z jednej strony, uwarunkowania międzynarodowe ograniczają pakistańskich decydentów, koncentrując ich uwagę oraz działania na utrzymaniu integralności terytorialnej i sprawach bezpieczeństwa. Już w momencie uzyskania niepodległości „na pakistańskiej armii i ruchu niepodległościowym ciążyła większa presja niż na armii indyjskiej (...). [Pakistańska armia] musiała poradzić sobie z ogromnym napływem uchodźców i wkrótce znalazła się w stanie wojny z Indiami o Kaszmir dysponując mniejszymi zasobami i mając więcej problemów niż armia indyjska”" ${ }^{\prime}$. Presję tą nasilił rząd w Kabulu, który tuż przed powstaniem Pakistanu „wypowiedział traktat, który zawarł Amir Abdurrahman w 1893 r. ustanawiając granicę z Indiami Brytyjskimi na linii Duranda"17. Z drugiej strony, te niekorzystne dla Pakistanu uwarunkowania międzynarodowe stanowią pretekst do zachowania dominującej pozycji establishmentu militarnowywiadowczego. Fakt, że kwestie Kaszmiru w relacjach z Indiami oraz wspólnej granicy w relacjach z Afganistanem pozostały nierozwiązane przez ponad 72 lata istnienia Pakistanu, $i$ w konsekwencji wciąż stanowią źródła napięć, prowokuje pytanie o przyczyny trwałości tych konfliktów.

Pakistan postrzega Indie jako wroga (i vice versa) niezmiennie od czasu podziału subkontynentu indyjskiego. „Cztery wojny [1947-1949, sierpień-wrzesień 1947, grudzień (3-16) 1965, maj-lipiec 1999] i niezliczone ataki terrorystyczne pakistańskich terrorystów w Indiach, podzielone okresami relatywnego pokoju i okazjonalnego dialogu, regularnie pobudzały wrogość między krajami" ${ }^{18}$ - jak o dynamice tych relacji bilateralnych, ignorując przy tym ewentualny udział Indii w eskalowaniu napięć, pisze Grare. Tapermanentna wrogość determinuje inne polityki Pakistanu. „Główne kierunki polityki bezpieczeństwa wytyczane są na

${ }^{16}$ P.Oldenburg, India, Pakistan and Democracy. Solving the Puzzle of Divergent Paths, Routledge, New York 2010, s. 46.

17 A. Sattar, Pakistan's Foreign Policy 1947-2005. A Concise History, Oxford 2007, s. 154.

18 F. Grare, India and Pakistan. Improbable War, Impossible Peace, [w:] Ch. Jaffrelot (red.), Pakistanat the Crossroads. Domestic Dynamics and External Pressures, Gurgaon 2016, s. 336. 
podstawie rzeczywistego bądź wykreowanego poczucia zagrożenia ze strony silniejszego sąsiada"19 - przyznaje Kuszewska. Dynamikę tych, w najspokojniejszych okresach co najwyżej chłodnych, relacji bilateralnych w znacznym stopniu determinuje konflikt o Kaszmir. Choć formalnie Dżammu i Kaszmir znajduje się pod kontrolą Chin (Aksai Chin, Dolina Saksgam), Indii (Dolina Kaszmiru, Dżammu, Ladakh) i Pakistanu (Gilgit Baltistan, Azad Dzammu i Kaszmir), Islamabad i Delhi na różne sposoby kwestionują ten podział. Jednak spór terytorialny nie jest wyłączną przyczyną napięć między pańtwami. Geneza wzajemnej wrogości jest bogatsza, i obejmuje upolitycznienie animozji między hindusami a muzułmanami, i w konsekwencji rozwój teorii dwóch narodów (zgodnie z którą wyznawcy tych dwóch religii potrzebują dla siebie dwóch różnych państw na subkontynencie indyjskim) oraz formowanie tożsamości narodowej w kontrze do sąsiada: „Pakistańskie elity były przekonane, że Pakistan jest tym wszystkim czym nie chcę stać się Indie"20.

Odwrotnie niż Indie, Afganistan stanowi zagrożenie dla bezpieczeństwa i integralności Pakistanu, nie ze względu na swoją potęgę, ale charakterystykę państwa upadłego. Do tego upadku, jak powszechnie zgadzają się badacze i praktycy stosunków międzynarodowych, doprowadziła ingerencja państw trzecich, a konkretnie zimnowojenna rywalizacja między Stanami Zjednoczonymi a Związkiem Radzieckim. Pakistan zaangażował się w wojnę sowiecko-afgańską (1979-1989), po stronie wspieranych przez Stany Zjednoczone mudżahedinów. Konsekwencje tego konfliktu jak ,wzrost radykalnego islamu, silny wpływ ISI i wojska na politykę zagraniczną i państwo cywilne - zaważyły na obecnej sytuacji Pakistanu"21.

Niezależnie od wysokiej ceny jaką zapłaciło pakistańskie społeczeństwo za udział w tej wojnie, w następstwie zamachów z 11 września 2001 r. Pakistan znów stał się stroną konfliktu toczonego na terytorium sąsiada. Udział w obu konfliktach „,napędzał wzajemny brak zaufania, tak samo między establishmentami jak i obywatelami”"22 Pakistanu i Afganistanu. Co więcej, wraz z zaangażowaniem Islamabadu w oba konflikty,

${ }^{19}$ A. Kuszewska, Zrozumieć Pakistan. Radykalizacja, terroryzm i inne wyzwania, Warszawa 2015, s. 276-277.

20 S. Wolf, The China-Pakistan Economic Corridor of the Belt and Road Initiative: Concept, Context and Assessment, Springer, 2019.

${ }^{21}$ Ch. Jaffrelot, A History of Pakistan and its Origins, New York, 2004, s. 107.

22 A. Kuszewska, A. Nitza-Makowska, Selected Aspects of Pakistan's Post-2013 Foreign Policy, «IAAPS [Indian Association of Asian and Pacific Studies] Perspective» 2017, vol. 2, s. 42. 
rosła pozycja pakistańskiego establishmentu militarno-wywiadowczego, którą legitymizowało poczucie zagrożenia ze strony upadającego sąsiada, od problemów którego Pakistan dzieli nieszczelna granica swobodnie przekraczana przez ekstremistów, oraz napływ amerykańskich środków. Ponad trzy dekady po zakończeniu wojny sowiecko-afgańskiej i 18 lat od czasu ataków z 11 września 2001 r. źródłami napięć na linii IslamabadKabul pozostają granica na linii Duranda, napływ afgańskich uchodźców do Pakistanu, transgraniczny terroryzm oraz działania państw trzecich (USA, Indie, Chiny) w Afganistanie.

Trudne relacje z Indiami i Afganistanem, determinują priorytety Pakistanu, którymi są ,zachowanie integralności terytorialnej (...) i posiadanie przyjaciół. Przyjaciół, od których można kupić broń"23. Islamabad nawiązał jedne z najtrwalszych relacji bilateralnych w Azji z Chinami. Ich sojusz ma decydujące znaczenie dla równowagi sił w regionie, w tym rywalizacji chińsko-indyjskiej. Historia relacji z drugim ze strategicznych partnerów, Stanami Zjednoczonymi jest bardziej dynamiczna. Stosunki te ulegały na przemian zacieśnieniu - jak po wojnie koreańskiej - i rozluźnieniu - gdy Islamabad przystąpił do budowy własnego programu atomowego. Konieczność posiadania ,przyjaciół” - od której relatywnie wolne są Indie - powoduje, że Pakistan zależy od swoich sojuszników, co z kolei prowokuje Stany Zjednoczone i Chiny do podporządkowywania Islamabadu własnym interesom $w$ regionie i na świecie. W konsekwencji, bilateralne stosunki Islamabadu z Pekinem i Waszyngtonem odpowiadają charakterystyce relacji między patronem (Chiny, USA) a klientem (Pakistan), gdzie patron ma pozycję, aby m.in. wymusić na kliencie działania, za które klient otrzymuje korzyści.

Waszyngton, który kreuje się na obrońcę demokracji - w różnym stopniu w zależności od okolicznościach geopolitycznych - utrwalał wewnętrznąnierównowagę kontroli w Pakistanie. Amerykańskie „wsparcie dla pakistańskiej armii (...) sprawiło, że słabemu świeckiemu społeczeństwu obywatelskiemu trudno było zostać zauważonym i oddzielić Pakistan od retoryki islamistycznej ideologii w sprawach ważnych dla obywateli"24. Jednak trudno ocenić w jakim stopniu Amerykanie wybrali sobie establishment militarno-wywiadowczy na partnera działań, a w jakim to wewnętrzna dynamika polityczna Pakistanu zmusiła ich do współpracy z aktorem, który dominuje na tamtejszej scenie politycznej.Pakistańska

${ }^{23}$ Ch. Jaffrelot, A History of Pakistan and its Origins..., s. 97.

${ }^{24}$ H. Haqqani, Pakistan. Between Mosque and Military, Lahore 2005, s. 311-312. 
klasa polityczna była zbyt słaba, aby wykonać zadania, na którym zależało sojusznikom w Waszyngtonie ${ }^{25}$ - ocenia Haqqani.

Uwarunkowania geopolityczne, najpierw wojna sowiecko-afgańska, później globalna kampania przeciwko terroryzmowi, powodowały zacieśnianie współpracy Waszyngtonu z pakistańskim establishmentem militarno-wywiadowczym. W okresie po 11 września 2001 r., operacja amerykańskich sił specjalnych uchwycenia i zabójstwa Osamy bin Ladena obnażyła hierarchiczną naturę tych relacji. Drugiego maja 2011 r. Waszyngton samodzielnie przeprowadzili operację w Abbottabadzie na terenie pakistańskiej prowincji Chajber Pachtunchwa, tym samym kompromitując tamtejsze służby dotychczasowego partnera swoich działań.

W okolicznościach załamania relacji z Waszyngtonem, Islamabad polegał na ,przyjacielu na każdą pogodę” w Pekinie. Te relacje bilateralne były tak głębokie, że Pekin „,był gotów zaoferować sojusznikowi najlepszy prezent jakie jedno państwo może dać drugiemu: materiały, których pakistańscy naukowcy potrzebowali do budowy bomby atomowej (...). Teraz Pakistan jest kluczowym elementem w transformacji Chin z siły regionalnej w globalną"26. Uwieńczeniem ponad 60-letniej współpracy politycznej, gospodarczej i militarnej jest bezprecedensowa, warta ponad 60 miliardów USD inwestycja, czyli Chińsko-Pakistański Korytarz Ekonomiczny (China-Pakistan Economic Corridor, CPEC), część chińskiej Inicjatywy Pasa i Drogi (Belt and Road Iniciative, BRI), który ma pobudzić pakistańską gospodarkę oraz pomóc zintegrować państwa Azji. W listopadzie 2014 r. Pakistan i Chiny podpisały 19 umów w ramach CPEC, który zakłada budowę sieci autostrad, linii kolejowych oraz infrastruktury energetycznej łączących port Gwadar w pakistańskim Beludżystanie z Kaszgarem w chińskim Sinciangu. Powstająca w ramach inwestycji infrastruktura (tak samo jak Chińczycy, którzy przyjeżdżają do Pakistanu) jest atrakcyjnym celem dla terrorystów i separatystów. Między innymi z uwagi na kwestie związane z bezpieczeństwem rozwoju CPEC, Pekin szuka wsparcia dla inwestycji wśród establishmentu militarno-wywiadowczego. Kreując ten establishment na gwaranta rozwoju CPEC, Chiny pogłębiają nierównowagę kontroli na pakistańskiej scenie politycznej.

25 H. Haqqani, Magnificent Delusions: Pakistan, the United States, and an Epic History of Misunderstanding, New York 2013, s. 325.

${ }^{26}$ A. Small, The China-Pakistan Axis: Asia's New Geopolitics, London 2015, s. 1. 


\section{Zakończenie}

Dwa demokratyczne przejęcia władzy w 2013 i 2018 r. nie zmieniły nierównowagi kontroli na pakistańskiej scenie politycznej. Pomimo bezprecedensowych dla Pakistanu warunków utrzymania ciągłości procesu wyborczego, w raporcie za 2017 r. FH wyłączył kraj z grona demokracji elektoralnych. Badania te pozostają spójne z oceną politologów, którzy unikając popełnienia błędu elektoralizmu klasyfikują Pakistan jako reżim hybrydowy. Przyczyną takiej oceny jest zależność polityków pochodzących z wyboru od establishmentu militarno-wywiadowczego, który steruje bieżącą dynamiką polityczną, w tym politykami w strategicznych dla Pakistanu obszarach jak bezpieczeństwo i sprawy międzynarodowe.

Choćby sposób w jaki od władzy odsunięto Nawaza Sharifa oraz innych polityków z PML(N) potwierdza dominującą pozycję establishmentu militarno-wywiadowczego. W warunkach utrzymania ciągłości procesu wyborczego nierównowagę kontroli na pakistańskiej scenie politycznej wciąż konstytuują (i) brak silnej klasy politycznej - ilekroć polityk (Zulfikar i Benazir Bhutto, Nawaz Sharif) - miał potencjał, aby rządzić niezależnie od establishmentu militarno-wywiadowczego, odsuwano go od władzy; (ii) nieformalny sojusz między establishmentem militarno-wywiadowczym a organizacjami religijnymi, w tym partiami islamistycznymi, oraz (iii) sposób $\mathrm{w}$ jaki prowadzona jest polityka zagraniczna Pakistanu, włączając eskalowane napięć z sąsiadami przede wszystkim z Indiami oraz skłonność sojuszników Stanów Zjednoczonych i Chin do podejmowania współpracy z pakistańskim establishmentem militarno-wywiadowczym.

Od uzyskania niepodległości sytuacja w państwie jest labilna, co pokazują m.in. badania nad trajektorią ustrojową Pakistanu prowadzone w ramach projektu Polity, zatem trudno ocenić prawdopodobieństwo przewrotu wojskowego w Pakistanie. Taki bieg wydarzeń wydaje się niekorzystny dla samego establishmentu militarno-wywiadowczego, który jest w stanie utrzymać równocześnie korzystną dla siebie nierównowagę kontroli oraz pozory demokracji. Co więcej, jak pokazuje historia Pakistanu, z przeprowadzeniem zamachu stanu zawsze wiązało się złożenie obietnicy demokratyzacji państwa - stąd tak duża dynamika trajektorii ustrojowej. Reżimy wojskowebyły w porównywalnym stopniuniestabilne jak rządy pochodzących z wyboru polityków. U schyłku każdej dyktatury wojskowej, m.in. pod wpływem presji społecznej, w końcu przeprowadzano wybory. Znacznie bardziej korzystne dla establishmentu militarno-wywiadowczego wydaje się promowanie przychylnych sobie 
polityków (i eliminowanie tych, którzy stanowią zagrożenie), przy zachowaniu pozorów demokratycznej konkurencji o władzę. W tym kontekście trzeba zauważyć, że sympatie establishmentu militarno-wywiadowczego często okazują się zmienne, czego doświadczyli Zulfikar Bhutto (odsunięty od władzy i zamordowany przez reżim Zii ul-Haqa, COAS, którego sam powołał) czy Pervez Musharraf. Dlatego trudno ocenić czy obecny premier Imran Khan utrzyma przychylność tego establishmentu, która, jak pokazuje historia ostatniego rządu PML(N), bywa ważniejsza dla funkcjonowania i utrzymania się na pakistańskiej scenie politycznej niż poparcie obywateli.

\section{Bibliografia}

K. Adeney, How to Understand Pakistan's Hybrid Regime: The Importance of aMultidimensional Continuum, «Democratization» 2017, nr 24 (1).

F.Grare, India and Pakistan. Improbable War, Impossible Peace, [w:] Ch. Jaffrelot (red.), Pakistan at the Crossroads. Domestic Dynamics and External Pressures, Random House India, Gurgaon, 2016.

H. Haqqani, Pakistan. Between Mosque and Military, Vanguard Books, Lahore 2005.

Ch. Jaffrelot, India and Pakistan: Interpreting the Divergence of Two Political Trajectories, «Cambridge Review of International Affairs» 2002, nr 2.

Ch. Jaffrelot, A History of Pakistan and its Origins, Anthem Press London, New York, 2004.

M.I. Khan, Why was Pakistan General Giving Money to Protesters? BBC News, 29.11.2017, http://www.bbc.com/news/world-asia-42149535 (3.02.2020).

P.Kłodkowski, Rządy Boga czy system demokracji - ideologiczny spór o kształt Republiki Islamskiej Pakistanu w XX i w XXI wieku, «Studia Politologiczne» 2019, vol. 53.

A. Kuszewska, Zrozumieć Pakistan. Radykalizacja, terroryzm i inne wyzwania, PWN, Warszawa 2015.

A. Kuszewska, A. Nitza-Makowska, Selected Aspects of Pakistan's Post-2013 Foreign Policy, «IAAPS [Indian Association of Asian and Pacific Studies] Perspective» 2017, vol. 2.

A. Nitza-Makowska, Różnice demokracji: Indie i Pakistan, Collegium Civitas, Warszawa 2019.

P.Oldenburg, India, Pakistan and Democracy. Solving the Puzzle of Divergent Paths, Routledge, New York 2010.

I.A. Rehman, How Zia Redefined Pakistan, «Dawn», https://www.dawn.com/news/1342765 (3.02.2020).

A. Sattar, Pakistan's Foreign Policy 1947-2005. A Concise History, Oxford University Press, Oxford 2007.

A. Shah, Pakistan: Voting Under Military Tutelage, «Journal of Democracy» 2019, nr 1.

A. Small, The China-Pakistan Axis: Asia's New Geopolitics, C Hurst \& Co Publishers Ltd, London 2015.

M. Tudor, The Promise of Power. The Origins of Democracy in India and Autocracy in Pakistan, Cambridge University Press, Cambridge 2013.

S. Wolf, The China-Pakistan Economic Corridor of the Belt and Road Initiative: Concept, Context and Assessment, Springer, 2019. 